\title{
Tamás Berek
}

\section{The Correlation between the Commander's CBRN Expertise and the Commander's Crucial Information Requirement ${ }^{1}$}

DOI 10.17047/HADTUD.2021.31.E.194

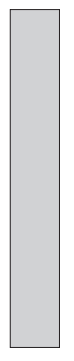

The CBRN environment of joint operations determines that future joint operations are to be planned and commanded in a way that considers the risks posed by CBRN weapons against the forces participating in such operations. In addition to that, materials detrimental to the health of personnel may be released from destroyed industrial plants and nuclear facilities. Consequently, friendly forces shall prepare not just for the protection against conventional attacks, but also for CBRN incidents to. The commander's critical information requirement has great importance during the operations planning period, and CBRN proficiency is critical in analyzing various sets of CBRN information.

KEYWORDS: CBRN threat, CBRN defence, CBRN expertise

\section{A parancsnok kritikus információigénye és $A B V$ jártasságának összefüggése}

A katonai müveletek $A B V$ környezete meghatározza, hogy a jövó múveleteit a múveletekben részt vevó erók ellen irányuló $A B V$ fegyverek alkalmazásának kockázatával kell tervezni és vezetni. Mindezek mellett a rombolódott ipari üzemekból és nukleáris létesítményekból is egészségre ártalmas anyagok szabadulnak ki. Következésképpen az erőinknek nem csak a hagyományos támadásokkal szembeni védelemre kell felkészülni, hanem ABV eseményekre is. A parancsnok kritikus információigényének nagy jelentösége van a müveletek tervezésének idôszakában, $A B V$ jártassága pedig meghatározó az $A B V$ információk elemzésében.

KULCSSZAVAK: $A B V$ fenyegetettség, ABV védelem, ABV jártasság

४ National University of Public Service, Budapest, Hungary -

Nemzeti Közszolgálati Egyetem, Hadtudományi és Honvédtisztképző Kar;

e-mail: berek.tamas@uni-nke.hu; https://orcid.org/0000-0001-8358-6139

1 The Project was realised in the Frame of the „Tématerületi Kiválósági Program 2019 Biztonságos Társadalom és Környezet" 


\section{Introduction}

Modern combat has an intense manoeuvring nature. The basic aim of troop manoeuvres is to create favourable conditions for delivering strikes and fires, and to protect own forces from enemy strikes and fires. The favourable conditions to execute manoeuvres during combat, which enable the development of tactical success, are created by open wings and wide gaps (characteristics of advanced land combat) and the intense mobility of the troops. ${ }^{2}$

The application of CBRN weapons - over and above the destructive factors reduces the opportunities of the commander leading the operations by restricting the manoeuvring ability. Therefore, the information received about the CBRN situation plays an important role in the commander's assessment of the tactical situation.

The success of operations rests on rich interactions between commanders and other key actors. Relevant knowledge from the operational area can enable the understanding of the operational environment, as well as the possible effects and their impact. ${ }^{3}$

\section{Crucial information requirement of the commander}

The main features of crucial information - among others - are as follows:

- it depends on the circumstances and predictable;

- sensitive to the time factor;

- it is applied by the commander and marked;

- it forms a link between the present and the future;

- it can be transferred verbally by well-defined means. ${ }^{4}$

Information received from the theatre of military operations to characterize the CBRN situation can be included here. To obtain this sort of information, it is necessary to employ organisational, supporting chemical defence subunits that have received secondary training and are subordinated to the commander. However, the forces and tools available for the commander are always limited. Thus, the components supporting the operations and accomplishing chemical and radiological reconnaissance shall be differentiated.

Operations executed in urban environment entail the risk that hazardous industrial materials may be released from industrial facilities as a result of their destruction, which could have been caused even by conventional weapons. The requirement of information about the CBRN situation is essential for commanding the rapid and very intense operations of urban combat and one should not forget that the activities of chemical and radiological subunits are made more difficult by the urban combat characterized by fire, barricades, dense smoke, and other impediments.

2 Berek 2006.

3 Jobbágy 2019.

4 Hajdú, Somorácz and Szabó et al. 1999. 
During the clarification of the mission - besides analysing the superior's concepts and examining the "facts and factors" - data available by the time the mission goal received has to be considered and the analysis of the combat mission received has to be executed. In order to assess the CBRN threat during the preparations for the CBRN reconnaissance of the theatre of operations and for the CBRN vulnerability analysis, as well as the evaluation of the field from CBRN defence aspect, the action should be executed to obtain the necessary information and to deploy the chemical and radiological reconnaissance subunit. It is impossible to continuously execute CBRN reconnaissance and observation.

CBRN observation includes the information obtained on CBRN equipment, the assessment of threats and the data of early reconnaissance concerning air, water and ground. All of them are key elements for avoiding contamination. ${ }^{5}$

The activities of the CBRN reconnaissance subunits should be focused on the areas where the enemy is expected to deploy CBRN weapons and where contamination from other sources may occur. It is essential to acquire knowledge on the deployment principles of CBRN weapons and their effects on the activities of the troops. The training should cover all these issues.

The defence measures concerning the personnel and specified by the commander in the interest of the combat formation make it more difficult to properly execute the tasks and the time required for the given activity. In order to reduce the psychical burden on the personnel, it is extremely important to justify that personal protective devices are obligatory to wear, as well as the period necessary for wearing these devices. The assessment and evaluation of the CBRN circumstances are important components of supporting the commander's decision in respect of the conditions, e.g. the application of antidote or prophylactic preparations, the reduction of the CBRN risk, and so forth. ${ }^{6}$

Looking either at the planning of operations or the execution phase, the commander continuously requires information that is updated by the changes that take place in the course of progress, concerning - among others - the CBRN threat, the CBRN circumstances and their effects on combat activities. Today's advanced warfare is characterized by the continuous and dynamic change of the combat activities and the combat environment affecting them (including the CBRN environment). The myriad of information from the theatre of operations and the status of joint operations should influence the commander's decisions, regardless the fact that decision-making is supported by the CBRN defence staff - at the joint forces level - or the CBRN defence officer, or the CBRN defence NCO.

The evaluation of the threat requires over and above the assessment of the enemy's capacities such as composition, location, abilities and intentions, and the assessment of vulnerability to CBRN weapons and Toxic Industrial Materials (TIMs).

When planning the operations, the areas endangered by the release of hazardous industrial substances (TIMs) should be avoided by keeping in mind the

5 Padányi, Halász, Földi 2013.

6 Berek 2010. 
principle of avoiding hazard, except if these areas cannot be diverted from an operational aspect or are especially important in the execution of the operation.

Connected to this, the weaknesses and strong points of the friendly forces are required crucial information for the commander. The vulnerability analysis integrated into the process of threat assessment is carried out during the CBRN reconnaissance evaluation of the theatre of operations, which is intended to find out vulnerabilities in the area of CBRN defence.

It shall be made possible to establish the deficiencies in the CBRN defence system of the troops. The organisational components of the CBRN defence, the subunits' CBRN protection gear and the CBRN defence preparation, as well as training form the aspects of examination.

Training is in fact a factor that substantially influences the execution of the CBRN defence duties. It is required in the operational field to maintain CBRN training if there is low operational risk of CBRN weapons deployment and to increase training if the operational risk is higher (medium). It is the duty of the CBRN defence officer to plan, execute and verify the CBRN defence training, furthermore, to make recommendations to the commander in the course of the operations executed by the subunit in the CBRN environment to increase the ability to survive and to continue the operations.

The tactical considerations of terrain evaluation are the following: ${ }^{7}$

- monitoring, firing and shooting (zones, opportunities);

- masking and camouflage (covering);

- obstructions (barricades);

- key areas, terrain features;

- approach and advance routes;

- passages (directions) suitable for movements.

For the commander the most important information is about the approach (advance) routes that can be used by friendly troops and by the enemy's troops, both on the ground and in the air. The enemy can considerably reduce the commander's freedom to manoeuvre if it contaminates these routes. Prompt and relevant information about the contaminated area is essential for selecting routes that avoid the contaminated area, especially if the units and subunits have to overcome the contaminated area because wearing personal protective device significantly increases the time for executing a given activity and it influences combat effectiveness.

The information standardized according to NATO STANAG 2112 on the chemical, radiological and biological reconnaissance should be collected by the CBRN reconnaissance subunits when the CBRN incident or the release of hazardous industrial substance of non-strike origin takes place or if such release is suspected. At the same time, the basic principles of the operations related to CBRN reconnaissance and survey, as well as that of the sampling operations have been unified. The knowledge of them fundamentally determines the planning calculations.

7 Hajdú, Somorácz and Szabó et al. 1999. 
The basic aim of CBRN reconnaissance is to detect and identify CBRN contamination. The detection of radiological contamination is less influenced by environmental factors, but the detection of chemical contamination is intensely influenced by them. Besides terrain features, soil type and coverage by vegetation, meteorological conditions significantly affect not only the spatial propagation of the biological and toxic warfare agents, but also the efficiency of detection. CBRN reconnaissance should produce information that describe the parameters of the CBRN incident available to the commander commanding the operations so that it can serve as an aid to decision-making to avoid CBRN hazards.

\section{The commander's expected CBRN expertise}

In order to present the commander's CBRN expertise with the related relationships and by stressing the main requirements one has to touch upon the level of the CBRN expertise required for the soldier. It is a requirement that can be expected of every soldier to recognize the signs indicating the deployment of CBRN weapons and to act effectively upon this information for their own survival. The soldiers should be aware of the CBRN hazard warning signs, should recognize the alarm and should be able to alert his subunit. He should possess the necessary skills to use his personal protective device. $^{8}$

In this context the soldier should be aware of the security limitations of their protective gear and gas mask. An unjustified, excessive misbelief of the protective abilities of these devices is just as dangerous as the external danger posed by CBRN agents. The soldier should not just know what level of defence the protective devices provide, or where they can be applied, but also against what limitations they have.

The problems above mentioned are related to putting on and taking off the protective gear and the gas mask, which make it clear that application skills are not equivalent to the knowledge of the protection levels of the devices, i.e. the knowledge how to put them on. Putting on and taking off should be continuously practised until the soldier is able to perform these actions not only with closed eyes, but also under external physical and psychological conditions and without hesitation. Is it really possible to deploy the protective devices that fast under fire, during a combat, and under the effect of combat stress? Certainly, practicing does not provide a $100 \%$ coverage to avoid panic reactions, but definitely decreases the possibility that such reactions develop. Talking still about soldiers' survival chances, it is not questionable that even if the soldier possesses the above described skills, this is still not sufficient as they are to survive and also carry out the mission. For this reason, these techniques have to be rehearsed during situational practices and numerous tactical exercises. Practicing is required day and night, in rain and in snow, in cold and in warm weather, in open country and in the woods and mountains. A soldier is to carry out his/her mission under all circumstances. Even with gas mask and in protective wear. This means that expertise and skills have to be developed,

8 Requirements of NBC defence expertise according to NATO standard, 2004, MH Ground Headquarters. 
and exercises suiting the basic mission should be regularly accomplished wearing CBRN protective gear. For instance, a rifleman should be able to handle his own personal firearm with almost the same efficiency as the collective weapons of his subunit, even in gas mask. This expertise can only be obtained by regular practicing.

The soldier should perform chemical and radiological reconnaissance in the interest of his own subunit and upon the order of his commander to establish the nature and rate of the CBRN hazard and for how long personnel should wear the protective devices. This reconnaissance activity should be performed as a member of the chemical and radiological, non-organisational reconnaissance patrol set up from the personnel of the subunit, using the reconnaissance devices put in service.

The soldier can accomplish this mission if he is not only aware of the reconnaissance devices but also he is able to operate them under real circumstances. It is sufficient to hold comprehensive preparations once to perform these missions, but the routine shall be established during daily practicing and during tactical exercises.

\section{The reference literature distinguishes the following methods of decision making}

- systematic (methodical) decision;

- decision made under combat situations (dynamic);

- quick decision;

- prompt reaction.

The systematic decision applied during the planning of the first military operation or combat activity makes it possible - due to its nature - to perform a comprehensive analysis. When making the decision under combat circumstances the staff does not carry out each analysis in full details but accomplishes its tasks by executing the most important steps and process of the components required from the aspect of planning the operations and the activities of combat. Quick decision. The stages of a quick decision are the same as in the case of the decision made under combat circumstances with the difference that even less time is available. This fact makes the detailed execution of individual process components even less possible. In case of immediate reaction, the commander has no possibility to apply the procedures and mechanisms described above, because of the fast changes in the circumstances.

Since the systematic decision applied during the planning phase of the joint operations or combat activity makes it possible, due to its nature, to perform a comprehensive analysis, an opportunity presents itself to verify the reliability of the data required. However, when making a dynamic decision under combat circumstances, planning is further complicated by time constraints. During the immediate reaction, the commander makes his own independent resolve based on his experience and his decision made during preparations. Thus, the commander delivers his/her decision to the subordinates without delay in the form of a verbal order. ${ }^{9}$

9 Hajdú, Somorácz and Szabó et al. 1999. 
The commander's proficiency and professional skills, as well as the detailed knowledge of the abilities and possibilities of subordinates are especially important to make the proper decision. The knowledge of the effects of CBRN weapons, the CBRN defence abilities of subordinates and their CBRN expertise are also important, for which the commander has to announce his critical information requirements.

The significance of the commander's intent is reflected by the fact that it is issued to the staff before making the decision of high importance from that aspect.

The commander's guide includes the time schedule, the preliminary concept and among others the assessment of risks (which I do not discuss here), the information required by the commander, the reserve forces and their composition and the conditions of reserve deployment. The assessment of CBRN vulnerability requires the analysis and evaluation of the CBRN defence capability and how the requirements for the protective gears of own troops have been met.

Commanders and their staffs should be capable of accomplishing the following: ${ }^{10}$

- to have knowledge of the organisational system and tools of the available CBRN defence;

- to assess the abilities of the professional CBRN defence forces under their command and use them in accordance with the regulations;

- to specify and execute the preparation and training for proper CBRN defence;

- to evaluate the effects exerted by CBRN incidents and the operational CBRN environment on own troops;

- to implement CBRN defence measures that correspond to the combat situation and the mission;

- to plan operations by taking CBRN threats into account and the defence ability of the commander's unit;

- to understand and assess the adverse health effects of wearing CBRN protective devices for a prolonged period and applying relief measures;

- to understand the basic principles of the philosophy of CBRN risk management;

- to understand the results and limitations of health measures, the operational and legal consequences of their implementations.

\section{Conclusions}

Military operations always involve the possibility of losses. The protection of forces and assets rest on the appropriate risk management and not on their exclusion. Accordingly, the requirements should appear in planning, execution and preparation, as well as in training. The protection of military forces and subunits pursuing combat activity equals the operation of a complex system that is based on the activities of support and security forces. This comprises the entirety of security regulations with the purpose of protecting facilities that are key for the forces, as well

10 ATP-3.8.1 (2011) CBRN Defence Standards for Education, Training and Evaluation. 
as the CBRN protective gear and the military forces. Efficiency is provided by the coordinated regulations built on each other and also complementing each other, which is realized in a joint effort. ${ }^{11}$

The CBRN defence officer, who analyses the information plans and the activities involving the deployment of CBRN defence subunits, has to make proposals. He/she has numerous tasks in planning, organizing and verifying the execution of the CBRN defence training and the preparation and implementation of the CBRN defence regulations. They:

- organize the collection of information on CBRN contamination and besides maintaining the map that register CBRN circumstances records including the radiation dose received by the subordinated and reinforcing forces;

- analyze, evaluate and forward the data connected to the weather; prepare measurements and report regarding the effect of CBRN contaminations on the execution of the mission (task);

- plan and organize chemical and radiological reconnaissance and make recommendations on the deployment of smokescreen devices;

- plan and organize the acquisition, storage and distribution of chemical protective devices and materials.

The staff should perform a huge amount of tasks in the course of decision-making. The selected methods should comply with numerous requirements in order to enable the staff to perform these tasks in due time and with appropriate contents.

The commander's requirement for crucial information makes it possible to direct the staff's efforts in the course of obtaining the information for making the decision that enables more efficient operations planning. "The commander's requirement for crucial information is for the aggregate of previously unknown data which data directly influence the successful execution of the military operation or combat and which are absolutely necessary for the commander's decision.."12

Accepting the fact that crucial sets of information have a direct impact on the tactical and operational activity and are therefore indispensable for the commander's decision, the requirement of the commander for critical information indirectly influences the successful execution of the operations.

With the changes in the tactical situation, the commander's requirement for crucial information obviously changes as change in the CBRN circumstances requires change in the CBRN defence regulations. This has to be done in accordance with the above plans to fundamentally influence the information requirement concerning the combat of own troops - among others - in respect of the radiation dose received by individuals and the cumulative radiation dose received by subunits.

To achieve that, the commander should announce his intent with tolerable accuracy together with his requirement on information concerning the CBRN circumstances towards his staff. The commander should be aware of the effects of CBRN weapons on the theatre of military operations as well as of the effects directly or indirectly affecting combat activity.

11 Padányi 2006.

12 Hajdú, Somorácz and Szabó et al. 1999. 
In addition to the fact that crucial information received from the battlefield have direct impacts on the execution of the combat mission, they also support the commander in reinforcing, approving or modifying the given military operation and combat activity, as well as in the assessment performed if the task assigned to the troops have been executed as planned by the superior. Furthermore, crucial information makes the phases recognisable where the deployment of CBRN defence plans among the plans of military branches become necessary.

\section{REFERENCES}

ATP-3.8.1 (2011) CBRN Defence Standards for Education, Training and Evaluation.

Berek, Lajos 2006. Manóverek a korszerú harcban. ("Manoeuvres in modern combat.") Hadmérnök 1 (1): 76-82.

www.hadmernok.hu/archivum/2006/1/2006_1_berek.html (Dowloaded: 24. 01. 2020.)

Berek Tamás 2010. A jövő tisztjeinek ABV védelmi felkészítésének iránya az ABV jártasság követelményeinek tükrében ("Directions of preparing future officers for CBRN defence in the light of the requirements of CBRN expertise.")

Hadmérnök 5 (2): 5-16. www.hadmernok.hu/2010_2_berek.php (Dowloaded: 24. 02. 2020.)

Berek Tamás 2013. Key elements of standards of proficiency for CBRN defence in military officers' education. Hadmérnök 8 (4): 33-39. http://www.hadmernok.hu/134_04_berekt.pdf (Dowloaded: 24. 02. 2020.)

Hajdú I., Somorácz A., Szabó Gy., Balogh Z., Bíró B., Fodor J., Téglási J., Horváth A., Magyar I. 1999. Törzsszolgálat, tankönyv. (Staff service, textbook.) Budapest: ZMNE.

Halász, László, Padányi, József, Földi, László 2013. “Improving the CBRN defence of combat vehicles as a response to the challenges of climate change." Economics and Management (Brno) 7 (3): 31-38.

Jobbágy, Zoltán 2019. The Effects of Joint Operations. Budapest: Nordex Nonprofit Kft. - Dialóg Campus Kiadó.

Padányi, József 2006. A katonai múveletek terrorvédelme. (Terrorism protection of military operations.) Nemzetvédelmi Egyetemi Közlemények 10 (3): 200-206.

Requirements of CBRN defence expertise according to NATO standard, 2004, MH Ground Headquarters. 